\title{
The Ghāzī Movement
}

Performative Religious Identity on the Byzantine-Islamic Frontier

\author{
Jessica L. Ehinger
}

This paper focuses on the role of Islamic religious identity in the broader question of emerging caliphal authority and its impact in rural settings - that is, how the rise of Islam and the emergence of the caliphate affected not just the nascent practice of Islam in rural communities, but what it meant to be a Muslim. Like many of the articles collected in this volume, it does so by focusing on one particular example, the $g h \bar{a} z \bar{\imath}$, a warrior-ascetic movement that developed on the frontier between the Byzantine empire and the caliphate in the late Umayyad and early Abbasid period (characterized here by the writings of Ibn al-Mubārak (d. 797) and Ibn Ishāa (d. ca. 8o2), as well as accounts of the life of Ibn Ādam (d. ca. 777)). Also like many of the other articles in this volume, both the subject and the setting play a key role in understanding the underlying textual themes - there was no one rural environment in the caliphate, and the various, diverse localities had their own challenges and needs based on their geography, environment, and the composition of the indigenous populations. The Byzantine-Islamic frontier was no different, and the rural and rugged environment itself figured centrally in much of the $g h \bar{a} z \bar{\imath}$ literature. ${ }^{1}$

The $g h \bar{a} z \bar{\imath}$ and their relationship to the indigenous population was similarly central - the ghāzi were predominately outsiders, many of them urban elite who had moved to the frontier in order to embrace an ascetic lifestyle. The local population were non-Muslims, but the ghāzi were crucially not missionaries - they understood the frontier to be hostile, and their purpose there was to subdue it, through military training and the purity of their own religious practices, not through conversion or outreach. In this way, there emerges in the Byzantine-Islamic frontier a distinct conception of religious identity in a rural setting, one in which many of the same contradictory themes that have been noted elsewhere in this volume come to light. The goal of the ghāzi was to sub-

1 For an overview on the developing character of the Byzantine-Islamic frontier, see chapter 4 of this volume from James Howard-Johnston, "Authority and Control in Interior of Asia Minor". See also A. Asa Eger, The Islamic-Byzantine Frontier: Interaction and Exchange among Muslim and Christian Communities (London: Tauris, 2015), 1-20. 
due the frontier, for the sake of Islam as a faith and for the caliphate, but their identity hinged on it remaining a hostile and remote territory, accessible only to them.

In doing so, the intention of this paper is also to bring to the foreground the concept of Muslim religious identity, which, unfortunately, still remains something of an 'unknown country' for the study of Islamic history. Although modern scholars are obviously aware that Islam is a religious movement, much of the scholarship about early Islam has focused on Islam as a military, political or social movement. The religious claims which underpinned this society seem to receive comparatively little attention. This is largely because the nature of Islamic practice and doctrine, or the definition of Muslim identity - what it meant to be a Muslim - in the first centuries of the Islamic expansion are questions hindered by the lack of surviving source material from much of the conquered territories. As will be discussed in more detail below, this lack of source material which can be consistently dated to the seventh or eighth centuries by modern scholars has created, in the words of Fred Donner, a field 'in a state of disarray,' ${ }^{2}$ with various scholars claiming that the early community who followed Muhammad and who conquered the Near East and North Africa should best understood as Tritheist Christians, Jewish Messianists, or Godfearing Abrahamic monotheists, with no clear methodological path to reunite this disparate theories. ${ }^{3}$

The continued academic fascination with understanding the religious identity of the early community of Muslims, despite the limited source material, however, is understandable, as the question of what it meant to be a Muslim in the seventh, eighth, and ninth centuries is inexorably tied to the larger question of how the Christian Near East and North Africa, territories which had been the cradle of Christianity since the life of Jesus Christ, transformed into the Muslim lands of the Medieval and modern periods, with their own distinctly Islamic society and culture.

2 Fred Donner, "The Qur'ān in Recent Scholarship: Challenges and Desiderata," in The Qur'an in its Historical Context, ed. Gabriel Said Reynolds (London: Routledge, 2008), 29.

3 Tritheist Christians are the suggested identity of Günter Lüling (Über den Ur-Qur'ān:Ansätze zur Rekonstruktion vorislamischer christlicher Strophenlieder im Qur'ān (Erlangen: Verlagsbuchhdlg, 1974)); Jewish Messianists of Patricia Crone and Michael Cook (Hagarism: The Making of the Islamic World (Cambridge: Cambridge University Press, 1977)), and Abrahamic 'Believers' is the analysis of Fred Donner (Muhammad and the Believers: At the Origins of Islam (Cambridge: Harvard University Press, 2010)). For a useful analysis of how this variety of theses has impacted early Islamic and Quranic studies, see also Angelika Neuwirth and Nicolai Sinai, "Introduction," in The Qur'ān in Context, eds. Angelika Neuwirth, Nicolai Sinai and Michael Marx (Leiden: Brill, 2011), 1-24. 
The ghāzi movement provides a useful outlet for discussing early Muslim religious identity for two reasons. On the one hand, the ghäzi provide a clear insight into one conception of how Muslims should live alongside the conquered communities of Christians and Jews, understanding Islam as superior to the other Abrahamic traditions, but without any emphasis on missionizing to the protected communities, using them instead as a religious Other, in order to define their own superiority. ${ }^{4}$ On the other hand, however, the ghāzi movement also demonstrates considerable distain for its Muslim co-religionists, elevating itself as a better form of Islam than that practiced elsewhere in the caliphate. In this way, it is possible to derive some information about what Islamic practice and Muslim identity may have looked like outside of the frontier, as well as how the particular character of the frontier affected that identity in the emergence of the ghāzi movement itself.

As has already mentioned, modern Islamic studies lacks a widely-accepted corpus of works for discussing the character of the early community of Muslims who first followed Muhammad and who made up the Muslim forces that expanded into the Near East in the early decades of the seventh century. Throughout much of the early twentieth century, scholars of Islamic history accepted the rough outlines of the Muslim tradition with regard to its early history; however, in the 1970s, several scholars pointed to the contemporary lack of any manuscript evidence for the Quran in the early seventh century and the claims within the Muslim tradition that much of Islamic thought was transmitted orally, in order to argue that there was not sufficient evidence to date Islam as a religion to the period of the lifetime of Muhammd or of the early expansion. ${ }^{5}$ Two of the most important competing theories for re-dating the emergence of a distinctly Muslim religious identity were those of Crone and Cook and that of John Wansbrough. As Crone and Cook argued, "there is no hard evidence for the existence of the Koran in any form before the last decade of the

4 For an overview on the role on the non-Muslim communities in this relationship, see David Harry Miller, "Frontier Societies and the Transition Between Late Antiquity and the Early Middle Ages," in Shifting Frontiers in Late Antiquity: Papers from the First Interdisciplinary Conference on Late Antiquity, ed. Hagith S. Sivan (London: Aldershot, 1996), 158-171.

5 For an account of the development of the field of Islamic studies in the twentieth and early twenty-first century, see Gabriel Said Reynolds' introduction in New perspectives on the Qur'an (London: Routledge, 2011). It is also worth noting that the recent discovery of a two-layer Quran, whose manuscript and lower layer date to the Uthmanic period, all but invalidates the issue of the lack of early source material for dating the work; see Behnam Sadeghi and Uwe Bergmann, "The Codex of a Companion of the Prophet and the Qurān of the Prophet," Arabica 57 (2010): 348-354; Behnam Sadeghi and M. Goudarzi, "Șan'ā' and the Origins of the Qurān," Der Islam 87, no. 1-2 (2012): 1-129. 
seventh century, and the tradition which places this rather opaque revelation in its historical context is not attested before the middle of the eighth. The historicity of the Islamic tradition is thus to some degree problematic: while there are no cogent internal grounds for rejecting it, there are equally no cogent external grounds for accepting it." 6

Similarly, Wansbrough drew on the same lack of extant material evidence for a seventh-century Qurān, and focused instead on the development of the broader Islamic written tradition, in particular the biographies of the Prophet and the codification of Islamic jurisprudence, which were all codified in the Abbasid period. He thus argued for this period as a more fitting intellectual context for the development of Islamic thought, with the Qurān arising out of the developing Muslim state as a form of communal identity. For Wansbrough, the composition of the Qurān was essentially the culmination of Islamic identity formation, rather than its starting point, and, he argued, "logically, it seems to me quite impossible that canonization should have preceded, not succeeded, recognition of the authority of scripture within the Muslim community."7

These arguments for dating the Quran itself to the Abbasid period have not been universally accepted by the field of Islamic studies. Indeed, many scholars have preferred to maintain a dating for the Quran which still roughly adheres to the Muslim tradition. In particular, Fred Donner has argued for the essentially problematic nature of Crone's and Cook's thesis and the later revisionist school, which he describes as the "skeptical approach" to Islamic historiography, that "it asks us to accept on faith - since there is no surviving evidence that the true origins of Islam are different than what is portrayed by Islamic tradition - perhaps radically different." 8

Nevertheless, the underlying premise of these works, that the Quraan and other Muslim sources could be the product of a very different cultural milieu, in Wansbrough's terms, than the one claimed by the Muslim tradition, remains a central problem for discussing the nature of early Muslim identity, and for understanding how, if at all, the early community who followed Muhammad understood themselves as a community distinct from the existing religious communities of the Near East.

Similarly frustrating for the modern scholar is any attempt to track the progress of the expansion of Islam as a religion outside the provincial capi-

6 Crone and Cook, Hagarism, 3.

7 John Wansbrough, Qur'ānic Studies: Sources and Methods of Scriptural Interpretation (Oxford: Oxford University Press, 1977), 202.

8 Fred M. Donner, Narratives of Islamic Origins: The Beginnings of Islamic Historical Writings (Princeton: Darwin, 1998), 26. 
tals, as the role of rural communities during the period of the expansion itself is almost impossible to discern from the surviving sources. Unlike the rise of Christianity in the Near East, which took hold in the already-present Roman Empire, with much of the history of the first centuries of Christianity involving the blending of Christian thought with Graeco-Roman culture and political tradition, ${ }^{9}$ the Islamic caliphate developed concurrently with the religion of Islam, and therefore it seems reasonable to presume that a blending of traditions took place not within the structure of the caliphate itself, but in the territories and indigenous traditions that Islam overtook in its expansion. To put it another way, Christianity integrated into an empire, through which it acquired territory; Islam integrated into territories, through which it formed an empire.

However, in both Christian and Muslim sources, Islam as both a political and religious community often appears to jump from city to city, with little discussion of the progress between major urban centers. Furthermore, both Christian and Muslim sources refer to the conquest, conversion or submission of entire cities. This submission is usually in the form of either siege and conquest, or capitulation - or, famously, in the case of Damascus, both - but once a city has capitulated and an Islamic authority has been put in place, the city is treated as part of the Islamic world. The implication is that the city itself has become Islamic. There is some evidence to suggest what this actually meant for the people of the city - in particular, the continued use and maintenance of churches suggests that Christian life in the Levant continued more or less unabated. ${ }^{10}$

However, with the exception of monastic communities, life in rural areas is almost invisible in these accounts, and there is almost no evidence for how the religion of Islam spread among rural communities in the earliest century of Islam. As one of the only available sources for rural religiosity during the period of the expansion, Christian monastic communities offer an interesting example of the Muslims' apparently passive approach to religious conversion. According to Muslim and Christian sources alike, the first caliph Abū Bakr (r.

The relationship between early Christianity and the Roman Empire is a subject to itself and far too vast to be considered here; The Cambridge Ancient History series remains one of the best general works on the subject, in particular Averil Cameron and Peter Garnsey, eds., The Cambridge Ancient History, vol. 13, The Late Empire (AD337-425) (Cambridge: Cambridge University Press, 1998) and Averil Cameron, Bryan Ward-Perkins and Michael Whitby, eds., The Cambridge Ancient History, vol. 14, Late Antiquity: Empire and Successors (AD 425-60o) (Cambridge: Cambridge University Press), 2001.

10 Nancy Khalek, Damascus after the Muslim Conquest: Text and Image in Early Islam (Oxford: Oxford University Press, 2011) and Hugh Kennedy, "The Melkite Church from the Islamic Conquest to the Crusades," The 17th International Byzantine Congress, Washington D.C. (1986), 325-343. 
632-634) instituted an official policy of leniency for the conquered peoples, marking out monks, and in some versions, stylites, as noncombatants, whom the Muslim army should leave undisturbed, presuming the monks refrain from attacking the Muslims or inciting rebellion. ${ }^{11}$ No comment is made about the monks' role as religious leaders or figureheads, nor about whether preaching, particularly to Muslims, constituted an act of rebellion.

Monastic sources provide some illustration of the day-to-day interactions between Muslims and rural Christian communities, as well. Anastasius of Sinai (d. ca. 70o), writing from the monastic community at Mt. Sinai, composed three collections of edifying stories about his brothers at Sinai and the local rural communities in Palestine. The Muslims only appear in a handful of these stories, and the surviving evidence does little to expand on how Islamic rule played out in the provinces. Thus, for example, in one story, Anastasius tells of a man named Sartabias, living in the Syrian countryside, who was cured of demon possession when his demon leaves to serve alongside the Muslims in their naval campaign against Constantinople. According to the demon, the demons of the Near East were prioritizing their actions, being ordered to travel with the Muslims and attack Constantinople as presumably causing more evil than possessing individual Christians. ${ }^{12}$ The story strongly implies that Sartabias was aware of the Islamic expansion, including that the Muslim forces were approaching Constantinople. However, the Muslims remain absent from his own area, where it is demons who accost him, not Muslims or Muslim rule.

11 For the caliphal injunction as preserved in Muslim texts, see Abu 'Abdullah Muhammad b. 'Umar b Wāqidī al-Aslamĩ, Futūḥ al-Shām, trans Sulaymān al-Kindī as: The Islāmic Conquest of Syria: A Translation of Futūhushām (London: Ta-Ha Publishing, 2005), 13, and as in Christian texts, see the reconstructed history of Dionysus of Tel Mahrē in ed. and tr. Andrew Palmer, The Seventh Century in the West-Syrian Chronicles (Liverpool: University Press, 1993), 145. The version in Palmer preserves a reference to stylites, along with monks more generally. It is also worth noting that the pact only survives in later works, and so may not be relevant to discussions of the seventh century. See also Philip I. AckermanLieberman, "The Muhammadan Stipulations: Dhimml Versions of the Pact of 'Umar," in Jews, Christians, and Muslims in Medieval and Early Modern Times: A Festschrift in Honor of Mark R. Cohen, eds. Arnold Franklin, Roxani Magariti and Marina Rustow (Leiden: Brill, 2014), 197-206.

$12 \mathrm{C} 1$, Ms. Vaticanus gr. $2592123^{\mathrm{v}}-124^{\mathrm{r}}$. Unfortunately, there is no published edition or translation of the complete third, or "C" collection, in which this story features. It is preserved in a single manuscript, Ms. Vaticanus gr. 2592, fols. 123-135, and to date, summaries or translations of only three of the eleven stories have been published. However, an edition and French translation has been prepared by André Binggeli for his doctoral dissertation at the Sorbonne, a published version of which is forthcoming. See also Jessica L. Ehinger, "Revolutionizing the Status Quo: Appeals to Normalcy in the Writings of Anastasius of Sinai," Studies in Late Antiquity (2018), forthcoming. 
Similarly, The Book of Governors, written by Thomas of Margā in the early eighth century, centers on the monastic life of the Nestorian community of Mesopotamia, in which the Muslims appear only a handful of times, as often as locals seeking aid from the monks as in the form of tyrannical rulers. ${ }^{13}$ However, there is little sense of competing Islamic religious claims or missionary actions in his stories. ${ }^{14}$ By comparison, Thomas regularly laments that his brothers have been seduced into other, competing Christian monasteries, in particular a Monophysite monastery in Apamea, which was, at least according to Thomas, run by a sorcerer. In this way, the focus of the history remains very clearly on the lives of Christians, orthodox and heterodox, while the Muslim authority quite literally sink into the background.

All in all, these stories produce an image of the rural communities as largely devoid of 'Islam' in any religious sense. Again, this system was obviously advantageous for the Muslim authority, as it allowed them to focus attention and manpower elsewhere, on the continued expansion of the empire, the development of urban centers, and the establishment and maintenance of the growing caliphal bureaucracy. ${ }^{15}$ Even the continued focus of these monastic works on

13 In the entire chronicle, there are four stories of the Muslims abusing monks, and four of Muslims seeking healing from the monks, or giving them a donation for healings they have performed. See E.A. Wallis Budge, ed. and trans., The Book of Governors: The Historia Monastica of Thomas, Bishop of Margâ A.D. 840 (London: Kegan Paul, Trench, Trübner and co., 1893), 1:153-155, 228-229, 238-244 and 329, for the cases of the Muslims abusing the monks, and volume 1:223-225, 287-289, 316-318, for healings.

14 Budge, Historia Monastica, 1:72. Although mass conversion of Christians to Islam remains a major fear of many Christian authors in the seventh and eighth centuries, and it is clear that conversion did eventually take place, there are limited sources from either Christians or Muslims of specific individuals or groups being forced to convert. One of the few examples are Christian martyrologies, which often focus on particular groups of outsiders who were forced to convert by the Muslim authority; for example, the story of sixty martyrs in Palestine, which survives in two versions, one of sixty soldiers in Gaza and the other of sixty pilgrims in Jerusalem. In both cases, the stories stress the martyrs outsider status (as prisoners of war) to explain why they were required to convert when the native Christian populations in the area were not. For more on the existing version of the sixty martyrs stories and their relationship to one another, see George L. Huxley, "The Sixty Martyrs of Jerusalem," Greek, Roman and Byzantine Studies 18 (1977): 369-374 and David Woods, "The 6o Martyrs of Gaza and the Martyrdom of Bishop Sophronius of Jerusalem," Aram 15 (2003): 129-150.

15 For more on how Muslim rule played out in the urban centers in Egypt, see Petra M. Sijpesteijn, "New Rule over Old Structures: Egypt after the Muslim Conquest," in Regime Change in the Ancient Near East and Egypt: From Sargon of Agade to Saddam Hussein, ed. Harriet Crawford (Oxford: Oxford University Press, 2007), 183-202, and for the Syrian and Mesopotamian areas, see Sidney Griffith, "From Polis to Madina: Urban Change in Late Antique and Early Islamic Syria," Past and Present 10, no. 6 (1985): 3-27 and Andrew 
heretical Christians, if it represents an accurate historical circumstance, might have proved useful for the Muslim authority, as it does suggest an environment where Christians were more concerned with fighting each other than in resisting Muslim rule. Indeed, it appears that the Monophysites and Nestorians may have actually aided the Muslims, or at the very least, discouraged resistance among their communities, as they recognized that the arrival of the Muslims offered the opportunity to upset the balance of power which had previously left them persecuted by the Byzantines. ${ }^{16}$ The Islamic sources from the seventh and early eighth centuries, for their part, appear to give no official policy for Islamic practice beyond the concept of allegiance, and any understanding of the religious obligations of Islam, the requirements for conversion, or the spiritual or soteriological benefits thereof, is distinctly lacking. ${ }^{17}$

Palmer, "Messiah and Mahdī: History Presented as the Writing on the Wall," in Polyphonia Byzantina: Studies in Honour of Willem J. Aerts, eds. Hero Hokwerda, Edmé R. Smiths and Marinus M. Woesthuis (Groningen: Egbert Forsten, 1993), 45-84.

16 Perhaps the clearest example of the possible complacency of the Christian populations in the Muslim expansion comes from the letters of the Nestorian Patriarch Ishoyabh III, who writes to his priests and bishops, instructing them how to meet with and speak to the Muslim authority in order to gain favor and undercut the Monophysite population in the area; see Ishoyabh III, Liber Epistularum, ed. Rubens Duval (Louvain: Impr. Orientaliste, 1904-1905), 14C, 251. Jacob of Edessa, similarly, suggests leniency for Christians who have married a Muslim, arguing that they should be allowed back into the church without rebaptism and allowed to continue to participate in church services, including the Eucharist, even if the priest doubts the sincerity of their desire to return to the church. Unfortunately, this question and answer admittedly only appears in the Harvard 93 manuscript of the second collection of Jacob's Replies to Addai, but Robert Hoyland has argued persuasively for these and the other additional replies of this collection as genuine; Harvard Ms. 93 , fols. $16^{\mathrm{b}}-18^{\mathrm{a}}$ as edited and translated in Robert G. Hoyland, Seeing Islam as Others Saw It: A Survey and Evaluation of Christian, Jewish and Zoroastrian Writings on Early Islam (Princeton: Darwin Press, 1997), 602-6o3. See also K.D. Jenner, "The Canons of Jacob of Edessa in the Perspective of the Christian Identity of his Day," in Jacob of Edessa and the Syriac Culture of His Day, ed. Bar ter Haar Romeny (Leiden: Brill, 2008), 101-112.

17 It is worth noting again that the lack of source material and agreed dating for what constitutes an early Muslim source does further complicate the issue of understanding how and why a concept of "conversion" to Islam came about. Nevertheless, the concept of cities or territories 'converting' as a whole through submission to Islamic rule can be seen in eighth and ninth century sources, suggesting that this had remained the concept of Islamic 'conversion' - see, for example, the conquest of Syria as preserved in al-Waqidī's, Futūh ash-Shām. See also Mahmoud Ayoub, "Religious Freedom and the Law of Apostasy in Islam," Islamochristiana 20 (1994): 75-91; Fred Halliday, "The Politics of the Umma: States and Community in Islamic Movements," Mediterranean Politics 7, no. 3 (2002), 20-41, and Richard W. Bulliet, Conversion to Islam in the Medieval Period: An Essay on Quantitative History (Cambridge: University Press, 1979). 
It was apparently only in the later part of the Umayyad period that Muslim preachers begin to appear in the countryside. One example was the $g h \bar{a} z \bar{\imath}$, or warrior-saints, in the frontier territory between the Islamic and Byzantine Empires. From their own descriptions of their work, it appears these teachers were working outside of the official state, which continued to require only allegiance, and it is easy to read much of their work as acting as subversives against the rulings of the official state, as well - in particular, in their attempts to rewrite Muslim practice. However, the movement never gained mainstream authority. Indeed, as will be demonstrated in a moment, it appears that the ghāzi movement actively resisted mainstream adoption of their practices, as one major aspect of their identity was their understanding of their own version of Islam as essentially better than mainstream Islam, an identity which would have lost all meaning if their practices were adopted by Muslims universally.

It is, of course, always problematic to speculate about the reasons behind religious movements and their relative success or failure. Paradox is hardly unknown in religious doctrine - some communities manage wide-spread missionary success while maintaining a doctrine as the tiny remnant of God's faithful, some inspire fervor whilst preaching moderation, and still others decry worldliness, but embrace technological advances for mission and conversion. The relative success or failure of sects and schisms is a question with sociological, political, linguistics, racial and ethnic ramifications, as well as theological, soteriological and philosophical ones, and in many ways, the actual reasons behind a person's conversion or conviction remain largely subjective. However, consideration of the ghāzi conception of Islam offers an interesting opportunity to understand the evolving nature of Islamic theology, in particular in terms of the movement's relationship to the Byzantine frontier and its predominately Christian population.

The ghāzi movement reached its peak in the early Abbasid period, but had its philosophical roots in the Umayyad period and, at least according to its adherents, even in the period of Muhammad and his Companions. Michael Bonner, in his work on the Byzantine-Islamic frontier, has identified three basic types of warrior-saints, each epitomized by an early Abbasid period figure: the eastern scholar turned frontiersman, characterized by the Iraqi jurist Abū Ishāàq al-Fazārī (d. ca. 8o2); the model of piety, characterized by Ibn al-Mubārak (d. 797), and the extreme ascetic, characterized by monastic leader Ibn Ādam (d. ca. 777).${ }^{18}$ Although these types differ in the particular

18 Michael Bonner, Aristocratic Violence and Holy War: Studies in the Jihad and the ArabByzantine Frontier (New Haven: American Oriental Society, 1996), ch. 4. 
manner in which they practiced, they share a great deal in common, enough to create a rough picture of the ghāzi theology.

The first, and perhaps most important element, was the war itself - it is not without reason that the ghāzi movement was focused on the frontier territory between the Byzantine and Islamic empires. Indeed, as Bonner has noted, eastern scholars, like Abū Ishāq, who wished to practice the warrior lifestyle they wrote and legislated about, moved west. ${ }^{19}$ This was not simply a frontier practice, and was not found in the frontier territories in North Africa or in Transoxania, but one particularly focused on the continued war with the Byzantines. In this model, the Byzantines served as the model for the ultimate enemy, but the frontier itself also took on a special significance, being kept in check by the continued presence of the $g h \bar{a} z \bar{\imath}$, without whom, presumably, it would fall back under Byzantine sway. In this formulation, the indigenous people of the frontier played a complicated, and at times paradoxical, role, being partly the potential new wealth of Muslims that the ghäzi could convert, but at the same time, also being remnants of the Byzantine world that the gha $z \bar{\imath}$ sought to destroy.

Closely related to this idea of continual warfare was that of jihād. The Islamic doctrine of jihād was still developing at this stage, and the precise distinction between true jihād and general warfare (harb) was still under debate. ${ }^{20}$ In general, much of the debate regarding the distinction between jihād and harb normally focused on the question of authority, in particular if the right to call for jihād rested solely with the caliph. Intriguingly, in the 'Book of War' (Kitāb al-Siyar) of Abū Ishạā, the question of authority is avoided altogether, with no explanation for who could, and could not, rightly call for jihād. ${ }^{21}$ Similarly, in the piety model of Ibn al-Mubārak, the authority to declare the rightness of jihād appears to fall to Ibn al-Mubārak himself

19 Bonner, Aristocratic Violence, 108-109. See also Michael Bonner, "The Naming of the Frontier: 'Awāsim, Thughūr, and the Arab Geographers," Bulletin of the School of Oriental and African Studies 75 (1992): 5-31.

$20 \quad$ Michael Bonner, "Some Observations Concerning the Early Development of Jihad on the Arab-Byzantine Frontier," Studia Islamica 75 (1992): 5-31; Fred Donner, "The Sources of Islamic Conceptions of War," in Just War and Jihad, eds. John Kelsey and John Turner Johnson (New York: Greenwood Press, 1991), 31-70.

21 Abū Ishāā's rules on jihād as preserved in Ibn Abī Shayba, al-Mușannaf, ed. 'Āmi al-'Umarī al-A’zamī (Hyderabad: Matba'a al-'Aziziyya, 1971), 6, 418-419, analysis of Abū Ishāa's original material from Bonner, Aristocratic Violence, 115. For more on the transmission history, see Scott C. Lukas, "Where are the Legal Hadith? A Study of the Musannaf of Ibn Abi Shayba," Islamic Law and Society 15, no. 3 (2008): 283-314. 
and to his followers, as he argued for the superiority of the practice of jihäd over that of the pilgrimage to Mecca (hajj). ${ }^{22}$

In the words of John Wansbrough, the ghäzi movement represents a shift in understanding of the progress of authority, seeing the authority of Muhammad passing not to the caliphs, but to a "clerical elite," by virtue of the association of their level of knowledge and piety. ${ }^{23}$ The ghāzi movement was not one of outright rebellion, but rather one of legal and spiritual subversion, in which the role of the caliph is simply unnecessary, thanks to the continued vigilance and piety of the ghäzi themselves. In one particularly illustrative story, when the caliph Hārūn al-Rashīd (r. 786-8o9), who attempted to re-imagine himself as a $g h \bar{a} z \bar{l}$-caliph, came to al-Raqqa, the people of the town flocked instead to see Ibn al-Mubārak, who happened to be visiting, as well, leaving the caliph to comment "this man is king, and not Hārūn, whom the people do not praise [unless threatened with] the whip and the cudgel."24

The final key element of the ghäzi theology is the asceticism of the movement. As well-observed by Bonner, the figure of Ibn Ādam serves as an extreme model - he was said to have survived for a year on only a single chick pea a night, ${ }^{25}$ and remarked that his favorite food was clay, that "I could take no food but clay until I meet God, so it might be made clear to me what is the source of haläl,"26 and to have sought out manual labor and hard work wherever he traveled. ${ }^{27}$ In general, his understanding of religious practice seems well-summarized in the words of his followers, that, "[true] abstinence is abstinence from that which is permitted." ${ }^{28}$ But while Ibn Ādam may mark the most extreme version of $g h \bar{a} z \bar{\imath}$ asceticism, all of the ghāzi show some form of asceticism, first and foremost in their decision to live on the frontier. ${ }^{29}$ They also

22 As preserved in Shams al-Dīn Muhammad b. Ahmmad al-Dhahabī, Siyar a’tām al-nubalā', ed. Shu'ayb al-Arna'ūt (Beirut: Mu'assasat al-Risālah, 1981), 8, 364-365. For more on the development of Ibn al-Mubārak's doctrine of jihād, see Christopher Melchert, "Ibn alMubārak's Kitāb al-Jihād and Early Renunciant Literature," in Violence in Islamic Thought from the Qur'ān to the Mongols, eds. Richard Gleave and Kristo-Nagy (Edinburgh: Edinburgh Press, 2015), 49-69.

23 John Wansbrough, The Sectarian Milieu (Oxford: Oxford University Press, 1978), 71-87.

24 Abū Bakr Ahmad b. 'Alī al-Khațīb al-Bagdādī, Ta’rīkh Baghdād (Cairo: Maktabat al-Khānjī, 1931), 10, 156-157.

25 Abū Nu’aym al-Isfahānī, Hilyat al-awliyā’’ wa-tabaqāt al-basha (Cairo: Maktabat al-Khanji, 1967), 8:29.

26 al-Isfahānī, Hilyat, 7:372-373.

27 al-Isfahānī, 7:387.

28 A quotation attributed to Abū Yūsuf al-Ghasūlī from Bonner, Aristocratic Violence, 129.

29 Although not directly relevant to this discussion, it is also worth noting that the $g h \bar{a} z \bar{\imath}$ 
all show some degree of conservatism in terms of practice, echoing, to some degree, the Ibn Âdam concept of abstinence from the permitted.

All of these elements, the interest in continued warfare, the isolation of authority among the practitioners, and the reliance on asceticism, suggest a movement of a special elect - the elect among the elect, as it were. None of these doctrines contradict Islamic belief more generally, although the $g h \bar{a} z \bar{\imath}$ conception of authority comes close at times, but instead offer a more religious alternative, a practice of Islam better - more rigorous, more pious, and altogether more strenuous - than the practice set down by the caliphs and the official authority. It was also a theology which never managed a significant challenge to that official authority, in terms of population, leadership or doctrine. Although the ghäzi movement would survive throughout the Abbasid period, it would remain a very distinctly fringe movement. ${ }^{30}$

Several problems with the $g h \bar{a} z \bar{\imath}$ theology are readily apparent. Firstly, the movement's focus on asceticism, like asceticism in Islam more generally, was potentially contradictory to the Qurān, which moderates against extreme asceticism, saying, "O ye who believe! Forbid not the good things which Allah hath made lawful for you, and transgress not."31 This idea of allowing the good things which God has provided does not forbid extreme asceticism, but it does at least imply that the practitioner of extreme asceticism gains nothing compared to the average Muslim, and seems to answer directly the claim of 'true abstinence' set up by Ibn Ādam's followers - there is no better abstinence obtained by abstaining from what God has permitted. However, asceticism in its myriad forms does survive in Islam, and its practitioners would even gain a certain level of authority from their practice.

The more important flaw in the ghāzi theology lies in its understanding of the frontier. The movement was underpinned by an understanding of the frontier as essentially hostile territory, in which it was the participants themselves

movement was predominately, although not exclusively, made up of men, and that there is a strong tenor of overt masculinity undercutting their asceticism. For an interesting discussion of how gender and sexuality fit into ghäzi asceticism, see Christian Sahner, "The Monasticism of My Community is Jihad": A Debate on Asceticism, Sex, and Warfare in Early Islam," Arabica 64, no. 2 (2017): 149-183.

30 Robert A. Campbell, "Leadership Succession in Early Islam: Exploring the Nature and Role of Historical Precedents," The Leadership Quarterly 19, no. 4 (2008): 426-438; P. von Sivers, "Taxes and Trade in the 'Abbāsid Thughūr, 750-962/133-351," Journal of the Economic and Social History of the Orient 25 (1982): 71-99.

31 Muhammad M. Pickthall, trans., The Glorious Qur'an (New York: Tahrike Tarsile Qur'an Inc., 2004), sura 5 , verse 87 . 
who were keeping the frontier from regressing out of Islam entirely. This idea of the frontier communities of $g h \bar{a} z \bar{z}$, half-warrior guardians and half-ascetic practitioners, is really only viable in a hostile world. Thus, as already mentioned briefly, the indigenous population of the frontier plays a complicated role in the view of the $g h \bar{a} z \bar{z}$.

There are mentions of the $g h \bar{a} z \bar{\imath}$ attempting to instruct them, in particular Abū Ishạa, but the continued focus on the ghāzi understanding of sunna (tradition), a view as conservative as possible, suggests that they were instructing the people in a manner that nearly guaranteed that they would not conform. Indeed, in one story, Abū Ishāàq discovered innovation (bid'ā) being taught by one of his students (in the form of Mu'tazilism, it appears), and rather than correcting him, he banished him from the community. ${ }^{32}$ Indeed, at least according to the biography by al-'Tjlì (d. ca. 210), Abū Ishāà was known for having taught correct behavior to the peoples of the frontier (addaba ahl al-thughür), much of al- 'Ijlì's discussion of his teaching style focuses on his exclusionism, banishing any preachers who appeared in the area from different schools and attempting to keep away anyone with government connections. ${ }^{33}$

In many ways, the ghāzi movement was not a missionary movement, but rather an attempt to recreate a particular Muslim lifestyle, which adherents understood as being inherited from Muhammad and his earliest Companions, with the indigenous, rural communities of the frontier playing the part of the pre-converted Arabs, a role which was only effective so long as they remained unconverted. The continued struggle to integrate Islam into the existing social structure of the Near East continued to play out in the urban centers of the area, as illustrated by the Umayyad and Abbasid caliphs continued use of both raiding parties and political negotiations to attempt to maintain authority in the area. ${ }^{34}$ Yet the image that develops from the $g h \bar{a} z \bar{\imath}$ movement is one of both homogeny and foreignness, with the frontier remaining both unconverted and uncultured, essentially a blank slate for the application of ghāzi teaching.

\footnotetext{
32 Bonner, Aristocratic Violence, 110.

33 al-Isfahānī, Hilyat, 7:254.

34 John Haldon and Hugh Kennedy, "The Arab-Byzantine Frontier in the Eighth and Ninth Centuries: Military Organisation and Society in the Borderlands," in Arab-Byzantine Relations in Early Islamic Times, ed. M. Bonner (Aldershot: Ashgate, 2004), 141-180 and Fred M. Donner, "Centralized Authority and Military Autonomy in the Early Islamic Conquests," in The Byzantine and Early Islamic Near East, vol. 3, States, Resources and Armies, eds. Averil Cameron and Lawrence I. Conrad (Princeton: Darwin Press, 1995), 337-36o.
} 
Undoubtedly part of the reason for the ghāzi movement remaining a fringe movement was because of the basic nature of their theology. Because the $g h \bar{a} z \bar{\imath}$ defined themselves as a separate elite, there were contradictory pressures within the movement to spread the ideology, but also to preserve the general majority to which it compared itself. However, beyond the ideological limitations of $g h \bar{a} z \bar{\imath}$ theology, there are practical reasons why the movement could not offer a significant challenge to the established authority of the caliphate, most importantly because they remained focused on the frontier with the Byzantine empire. As the theological significance of warfare with the Byzantines was pushed farther into an eschatological future, the underlying claims of the ghäzi movement became less pressing to the larger community of Muslims.

Intriguingly, however, some of the movement's methodology and theology would be revived in the post-Abbasid period, as many of the ghāzi writers were drawn upon as models in the period in which the direct, political authority of the caliphate was replaced with the implied, spiritual authority of the 'ulam $\bar{a} .^{35}$ Whereas the ghāzi preachers rejected innovation and attempted to maintain a strict definition of right practice, however, the model that emerged with the 'ulam $\bar{a}$ ' was one of considerable variety, with the major schools preserving regional variation. Rather than serving as a practice of Islam better than that practiced by others, the same philosophical model was used to create a religio-legal system that accepted that some variation in practice was necessary, and set out instead to delineate the satisfactory range for that variation.

Indeed, the practice of Islam in rural areas continued to play a role in this on-going conversation about variation in practice, with the emerging schools of Islamic law developing regulations for when it was acceptable to postpone or omit practices due to limited resources, often calling on examples from rural life, such as the exceptions to the rules for fasting during long journeys, or the acceptable forms of ablution when no water was available, circumstances which easily conjure rural and frontier imagery. ${ }^{36}$ That Islamic law would come to accept significant variation in practice in rural environments perhaps suggests that Islam itself came to accept that it lacked the infrastructure in rural areas effectively to require strict adherence to ritual practices, although sig-

35 Donner, "Centralized Authority," 337-36o; Meir J. Kister, "Social and Religious Authority in Islam," Jerusalem Studies in Arabic and Islam 18 (1994): 84-127.

36 Richard Gauvain, "Ritual Rewards: A Consideration of Three Recent Approaches to Sunni Purity Law," Islamic Law and Society 12, no. 3 (2005): 333-393 and Marion Hohmes Katz, Body of Text: the Emergence of the Sunnī Law of Ritual Purity (Albany: SUNY Press, 2002). 
nificantly more research into how Islamic law was executed in the countryside would be needed, an examination of which is beyond the scope of this work.

In this way, both the ghāzi movement itself and its failure to find support in mainstream Islamic theology offer a small, but important, insight into how Islamic theology played out outside of the conquered urban centers of the Near East. In the ghāzi preachers' emphasis on performing more than was required for Muslims, outlines of the nascent Islamic ritual practices can be seen, particularly with regard to the requirements for fasting, pilgrimage, and the emerging conceptions of jihād. Their occupation of the frontier and emphasis on rural living as necessary for their practice similarly suggests that even as late as the Abbasid period, more mainstream forms of Islam had not significantly penetrated beyond the conquered urban centers of Syria, Palestine and Mesopotamia. This vision of the countryside as devoid of Islam coincides closely with the albeit limited source material from Christian authors, in which Islam and Muslim rule remain a city concern, appearing infrequently in the rural communities, if at all. Finally, although the ghäzi movement itself would never prove any kind of major threat to caliphal authority in Islam, their model of authority through spiritual devotion and intellectual superiority would prove successful in the emergence of the 'ulam $\vec{a}$ ' as the ultimate authority of Islamic theology and practice. However, whereas the ghāzi understood themselves as serving to exert the rule of Islam over the unconquered frontier, the image that would arise from the later codification of Islamic law was one of variation and adaptation, one in which 'ulam $\bar{a}$ ' appear ultimately to accept the essentially unconverted nature of the countryside.

Thus, both the ghāzi movement itself and the Byzantine-Islamic frontier in which it emerged provide important illustrations of many of the larger themes relevant to understanding the emergence of the caliphate in rural environments. First and foremost, the frontier itself played a crucial role in ghäzi theology, and the politicization of the frontier, and of the ghāzi themselves, hinged on it remaining a place of the "Other" - inhospitable and unconverted. Like many of the rural territories discussed in this volume, the Byzantine-Islamic frontier played a symbolic role for the ghāzi, but rather than serving as a symbolic extension of an existing urban institution - be it a tax district or an ecclesiastical See -, the frontier served as the symbolic lack of such institutions, acting as the "Other" to the caliphal authority and growing institutional establishment, an othering maintained by the $g h \bar{a} z \bar{\imath}$ preachers apparent uninterest in interacting with either the caliphal and the growing, urban 'ulam $\bar{a}$ ' authority.

The ghāzi preachers themselves also provide insight into how Muslim religious identity played out in rural settings. As has already been said, the develop- 
ing schools of Islamic law provided considerable lenience to Islamic practice in rural settings, perhaps suggesting that the established, urban ulam $\vec{a}^{3}$ authority did not see Islam as successfully taking hold in rural environments. The ghāzi rejected this idea, actively encouraging a kind of Islamic performance that was more than what was normally required - more fasting, more labor, more active military service - but their identity remained very much a performance, and the stories of their asceticism quickly plunge into absurdity. Moreover, their identity again stands outside the larger historical developments taking place in the Abbasid caliphate, and as much as the historical record suggest that individual ghāzi preachers were honoured as folk heroes, their religious movement found little widespread support. Here again, the ghāzi $\bar{s}$ seem to be defined by what they are not - neither truly rural themselves (as most preachers were urban transplants who moved to the frontier to practice asceticism), nor tied back to any of the larger institutions developing with the caliphate.

In this way, the ghāzi movement provides an important insight into the ultimately impenetrable nature of the rural environments that became part of the Umayyad and Abbasid caliphates. Although functionally part of the caliphate, the Byzantine-Islamic frontier was as much defined by its Otherness as a part of the caliphate, and the preachers who were drawn there were similarly defined by their distinct role as apart from both the indigenous rural community and the urban institutions they were rejecting by their absence. Hence, they demonstrate the decentralization of the rural environment, a decentralization so engrained as to become part of the identity of the region itself.

\section{Bibliography}

\section{Primary Sources}

Anastasius of Sinai. Narrat. C-collection = Ms. Vaticanus gr. 2592, fols. 123-135.

al-Dhahabī, Shams al-Dīn Muhammad b. Aḥmad. Siyar a’lām al-nubalā'. Edited by Shu’ayb al-Arna’ūt. Beirut: Mu’assasat al-risālah, 1981.

Ibn Abī Shayba. al-Muṣannaf. Edited by 'Āmi al-'Umarī al-A’zamī. Hyderabad: Matba’a al-'Aziziyya, 1971.

Ishoyabh III. Liber Epistularum. Edited by Rubens Duval. Louvain: Impr. Orientaliste, 1904-1905.

Wāqidī al-Aslamĩ, Abu 'Abdullah Muḥammad b. 'Umar. Futūh al-Shām. Translated by Sulaymān al-Kindī as: The Islāmic Conquest of Syria: A Translation of Futūhushām. London: Ta-Ha Publishing, 2005. 


\section{Secondary Sources}

Ackerman-Lieberman, Philip I. "The Muhammadan Stipulations: Dhimml Versions of the Pact of 'Umar." In Jews, Christians, and Muslims in Medieval and Early Modern Times: A Festschrift in Honor of Mark R. Cohen, edited by Arnold Franklin, Roxani Magariti and Marina Rustow, 197-206. Leiden: Brill, 2014.

Ayoub, Mahmoud. "Religious Freedom and the Law of Apostasy in Islam." Islamochristiana 20 (1994): 75-91.

Bonner, Michael. "The Naming of the Frontier: 'Awāsim, Thughūr, and the Arab Geographers." Bulletin of the School of Oriental and African Studies 75 (1992):5-31.

Bonner, Michael. "Some Observations Concerning the Early Development of Jihad on the Arab-Byzantine Frontier." Studia Islamica 75 (1992): 5-31.

Bonner, Michael. Aristocratic Violence and Holy War: Studies in the Jihad and the ArabByzantine Frontier. New Haven: American Oriental Society, 1996.

Budge, E.A. Wallis, ed. and trans. The Book of Governors: The Historia Monastica of Thomas, Bishop of Margâ A.D. 840. 2 vols. London: Kegan Paul, Trench, Trübner and co., 1893 .

Bulliet, Richard W. Conversion to Islam in the Medieval Period: An Essay on Quantitative History. Cambridge: Harvard University Press, 1979.

Cameron, Averil, and Peter Garnsey, eds. The Cambridge Ancient History, vol. 13, The Late Empire (AD337-425). Cambridge: Cambridge University Press, 1998.

Cameron, Averil, Bryan Ward-Perkins and Michael Whitby, eds. The Cambridge Ancient History, vol. 14, Late Antiquity: Empire and Successors (AD425-60o). Cambridge: Cambridge University Press, 2001.

Campbell, Robert A. "Leadership Succession in Early Islam: Exploring the Nature and Role of Historical Precedents." The Leadership Quarterly 19, no. 4 (2008): 426-438.

Crone, Patricia, and Michael Cook. Hagarism: The Making of the Islamic World. Cambridge: Cambridge University Press, 1977.

Donner, Fred M. "The Sources of Islamic Conceptions of War." In Just War and Jihad, edited by J. Kelsey and J.T. Johnson, 31-70. New York: Greenwood Press, 1991.

Donner, Fred M. "Centralized Authority and Military Autonomy in the Early Islamic Conquests." In The Byzantine and Early Islamic Near East, vol. 3, States, Resources and Armies, edited by A. Cameron and L.I. Conrad, 337-36o. Princeton: Darwin Press, 1995 .

Donner, Fred M. Narratives of Islamic Origins: The Beginnings of Islamic Historical Writing. Princeton: Darwin Press, 1998.

Donner, Fred M. "The Qurān in Recent Scholarship: Challenges and Desiderata." In The Qur'an in its Historical Context, edited by Gabriel Said Reynolds, 29-5o. London: Routledge, 2008.

Donner, Fred M. Muhammad and the Believers: At the Origins of Islam. Cambridge: Harvard University Press, 2010. 
Eger, A. Asa. The Islamic-Byzantine Frontier: Interaction and Exchange among Muslim and Christian Communities. London: Tauris, 2015.

Ehinger, Jessica L. "Revolutionizing the Status Quo: Appeals to Normalcy in the Writings of Anastasius of Sinai." Studies in Late Antiquity (2018), forthcoming.

Gauvain, Richard. "Ritual Rewards: A Consideration of Three Recent Approaches to Sunni Purity Law." Islamic Law and Society 12, no. 3 (2005): 333-393.

Griffith, Sidney H. "From Polis to Madina: Urban Change in Late Antique and Early Islamic Syria." Past and Present 10, no. 6 (1985): 3-27.

Griffith, Sidney H. "The Melkite Church from the Islamic Conquest to the Crusades." In The 17th International Byzantine Congress, Washington D.c. (1986), 325-343.

Haldon, John, and Hugh Kennedy. "The Arab-Byzantine Frontier in the Eighth and Ninth Centuries: Military Organisation and Society in the Borderlands." In ArabByzantine Relations in Early Islamic Times, edited by M. Bonner, 141-180. Aldershot: Ashgate, 2004.

Halliday, Fred. "The Politics of the Umma: States and Community in Islamic Movements." Mediterranean Politics 7, no. 3 (2002): 20-41.

al-Khațīb al-Bagdādī, Abū Bakr Ahmad b. 'Alī. Ta'rīkh Baghdād. Cairo: Maktabat alKhānjī, 1931.

Hohmes Katz, Marion. Body of Text: the Emergence of the Sunnī Law of Ritual Purity. Albany: SunY Press, 2002.

Hoyland, Robert G. Seeing Islam as Others Saw It: A Survey and Evaluation of Christian, Jewish and Zoroastrian Writings on Early Islam. Princeton: Darwin Press, 1997.

Huxley, George L. "The Sixty Martyrs of Jerusalem." Greek, Roman and Byzantine Studies 18 (1977): 369-374.

al-Isfahānī, Abū Nu’aym. Hilyat al-awliyā’’ wa-tabaqāt al-bashar. 10 vols. Cairo: Maktabat al-Khanji, 1967 .

Jenner, K.D. "The Canons of Jacob of Edessa in the Perspective of the Christian Identity of His Day." In Jacob of Edessa and the Syriac Culture of His Day, edited by Bar ter Haar Romeny, 101-112. Leiden: Brill, 2008.

Khalek, Nancy. Damascus after the Muslim Conquest: Text and Image in Early Islam. Oxford: Oxford University Press, 2011.

Kister, M.J. "Social and Religious Authority in Islam." Jerusalem Studies in Arabic and Islam 18 (1994): 84-127.

Lukas, Scott C. "Where are the Legal Hadith? A Study of the Musannaf of Ibn Abi Shayba." Islamic Law and Society 15, no. 3 (2008): 283-314.

Lüling, Günter. Über den Ur-Qur'ān: Ansätze zur Rekonstruktion vorislamischer christlicher Strophenlieder im Qur'ān. Erlangen: Verlagsbuchhdlg, 1974.

Melchert, C. "Ibn al-Mubārak's Kitāb al-Jihād and Early Renunciant Literature." In Violence in Islamic Thought from the Qur'ān to the Mongols, edited by Richard Gleave and Kristo-Nagy, 49-69. Edinburgh: Edinburgh Press, 2015. 
Miller, David Harry. "Frontier Societies and the Transition between Late Antiquity and the Early Middle Ages." In Shifting Frontiers in Late Antiquity: Papers from the First Interdisciplinary Conference on Late Antiquity, edited by Hagith S. Sivan, 158-171. London: Aldershot, 1996.

Neuwirth, Angelika, and Nicolai Sinai. "Introduction." In The Qur'ān in Context, edited by Angelika Neuwirth, Nicolai Sinai and Michael Marx, 1-24. Leiden: Brill, 2011.

Palmer, Andrew. "Messiah and Mahdī: History Presented as the Writing on the Wall." In Polyphonia Byzantina: Studies in Honour of Willem J. Aerts, edited by H. Hokwerda, E.R. Smiths, and M.M. Woesthuis, 45-84. Groningen: Egbert Forsten, 1993.

Palmer, Andrew, ed. and trans. The Seventh Century in the West-Syrian Chronicles. Liverpool: University Press, 1993 .

Pickthall, Muhammad M., trans. The Glorious Qur'an. New York: Tahrike Tarsile Qur'an Inc, 2004 .

Sadeghi, Behnam, and M. Goudarzi. "Șan'ā’ and the Origins of the Qur’ān." Der Islam 87, no. 1-2 (2012): 1-129.

Sadeghi, Behnam, and Uwe Bergmann. "The Codex of a Companion of the Prophet and the Qur'ān of the Prophet." Arabica 57, no. 4 (2010): 348-354.

Sahner, C. “"The Monasticism of My Community is Jihad”: A Debate on Asceticism, Sex, and Warfare in Early Islam." Arabica 64, no. 2 (2017): 149-183.

Said Reynolds, Gabriel. New perspectives on the Qur'an. London: Routledge, 2011.

Sijpesteijn, Petra M. "New Rule over Old Structures: Egypt after the Muslim Conquest." In Regime Change in the Ancient Near East and Egypt: From Sargon of Agade to Saddam Hussein, edited by Harriet Crawford, 183-202. Oxford: Oxford University Press, 2007.

Sivers, P. von. "Taxes and Trade in the 'Abbāsid Thughūr, 750-962/133-351." Journal of the Economic and Social History of the Orient 25 (1982): 71-99.

Wansbrough, John. Qur'ānic Studies: Sources and Methods of Scriptural Interpretation. Oxford: Oxford University Press, 1977.

Wansbrough, John. The Sectarian Milieu. Oxford: Oxford University Press, 1978.

Woods, David. "The 6o Martyrs of Gaza and the Martyrdom of Bishop Sophronius of Jerusalem." Aram 15 (2003): 129-15o. 